\title{
Замена туннельных переходов в структурах на основе InP на каналы проводимости.
}

\author{
А.Е. Маричев ${ }^{1}$, В.С. Эполетов ${ }^{1}$, А.С. Власов ${ }^{1}$, А.И. Лихачев ${ }^{1}$, А.В. Нащекин ${ }^{1}$, Б.В. Пушный ${ }^{1}$ \\ ${ }^{1}$ Физико-технический институт им. А.Ф.Иоффе, Санкт-Петербург, 194021, Политехническая, 26 \\ тел:+7 (960) 2625145, эл.nочта: aemarichev@mail.ioffe.ru
}

DOI 10.34077/RCSP2021-122

В настоящее время, наиболее эффективные фотоэлементы изготавливаются на основе каскадных гетероструктур. В таких приборах фотоактивные $\mathrm{p}-\mathrm{n}$-переходы, работающие в разных спектральных диапазонах, соединяются последовательно туннельными переходами с предельно высокими уровнями легирования $[1,2]$. При достаточно высокой плотности излучения, генерируемый фототок может превысить пиковый ток туннельных переходов, что ведет к увеличению сопротивления всей структуры и падению эффективности работы прибора [3].

В приборах на основе фосфида индия сложно получить качественные туннельные переходы из-за особенностей легирования фосфида индия примесями р типа большой концентрации.

Возможным путем решения является замена туннельных переходов на каналы проводимости, например, получаемые посредством создания массива микрокристаллических включений в области объемного заряда (ОО3) между соседними фотоактивными слоями n и р типа. [1].

Предложено использовать микрокристаллические массивы на основе GaP. Особенности таких массивов кристаллитов $\mathrm{GaP}$ и их получение на слое InP представлены в работе [4].

В настоящей работе представлены результаты исследований вольтамперных характеристик (BAX) p-n перехода с кристаллитами $\mathrm{GaP}$ в области объемного заряда и особенности протекания тока через такой p-n переход, исследованные методом ТИЭЗ (тока, индуцированного электронным зондом).

Метод ТИЭЗ позволяет анализировать электрические характеристики структур в объеме без создания омических контактов. Низкоомные контакты к p-InP [5] сложно изготавливать и это влияет на измерения характеристик таких структур.

В работе было показано, что метод ТИЭЗ позволяет выявлять особенности протекания тока через р$\mathrm{n}$ переход при введении кристаллитов $\mathrm{GaP}$ в $\mathrm{OO}$ структуры. В случае, когда размеры кристаллитов больше ширины ООЗ, происходит закорачивание $\mathrm{p}$-n перехода. Качество материала, выращенного поверх кристаллитов оценивалось методом фотолюминесценции и позволяет создавать фотоактивные области, о чем свидетельствуют результаты фотолюминесцентных исследований.

\section{Литература}

[1] Алфёров Ж.И., Андреев В.М., Румянцев В.Д., ФТП, т.38. в.8. с.937- 948, (2004).

[2] Karam N.H., Sherif R.A., King R.R. в сб. Concentrator photovoltaics под ред. Luque A.L., Andreev V. Springer Ser. in Optical Sciences (Springer, Berlin-Heidelberg, 2007).. Vol. 130. p. 199-219.

[3] Andreev V.M., Ionova E.A., Larionov V.R., Rumyantsev V.D., Shvarts M.Z., Glenn G. in 2006 IEEE 4th World Conference on Photovoltaic Energy Conference (IEEE, Hawaii, 2006), Vol.1 p. 799-802.

[4] Р.В. Левин, А.Е. Маричев, Е.В. Контрош, Н.Д. Прасолов, В.С. Калиновский, Б.В. Пушный, Письма в ЖТФ, 2018, Т.44, вып. 24.

[5] Эполетов В.С., Маричев А.Е., Пушный Б.В., Салий Р.А. Письма в ЖТФ, 2020, Т. 46, вып. 23. 